\title{
CrimRxiv
}

\section{Police Matters: The Everyday State and Caste Politics in South India, 1900-1975}

\section{Radha Kumar}

Published on: Mar 05, 2022

License: Creative Commons Attribution 4.0 International License (CC-BY 4.0). 
